TREND Statement Checklist

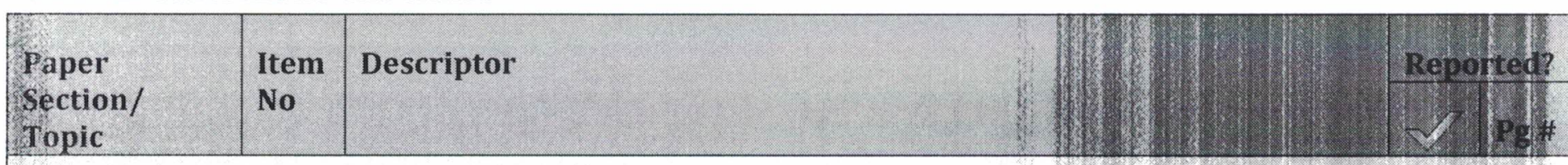

\title{
Title and Abstract
}

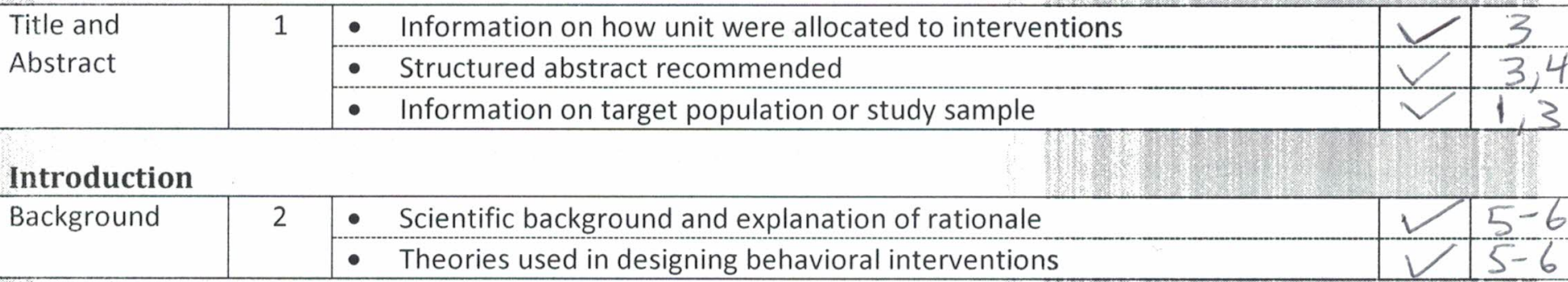

\section{Methods}

\begin{tabular}{|c|c|c|c|}
\hline \multirow[t]{4}{*}{ Participants } & \multirow[t]{4}{*}{3} & $\begin{array}{l}\text { - Eligibility criteria for participants, including criteria at different levels in } \\
\text { recruitment/sampling plan (e.g., cities, clinics, subjects) }\end{array}$ & \\
\hline & & $\begin{array}{l}\text { Method of recruitment (e.g., referral, self-selection), including the } \\
\text { sampling method if a systematic sampling plan was implemented }\end{array}$ & 6 \\
\hline & & - Recruitment setting & \\
\hline & & - Settings and locations where the data were collected & \\
\hline \multirow[t]{9}{*}{ Interventions } & \multirow[t]{9}{*}{4} & $\begin{array}{l}\text { Details of the interventions intended for each study condition and how } \\
\text { and when they were actually administered, specifically including: }\end{array}$ & \\
\hline & & Content: what was given? & \\
\hline & & Delivery method: how was the content given? & \\
\hline & & Unit of delivery: how were the subjects grouped during delivery? & \\
\hline & & $\circ$ Deliverer: who delivered the intervention? & \\
\hline & & - Setting: where was the intervention delivered? & \\
\hline & & $\begin{array}{l}\text { Exposure quantity and duration: how many sessions or episodes or } \\
\text { events were intended to be delivered? How long were they } \\
\text { intended to last? }\end{array}$ & \\
\hline & & $\begin{array}{l}\text { T Time span: how long was it intended to take to deliver the } \\
\text { intervention to each unit? }\end{array}$ & \\
\hline & & 0 Activities to increase compliance or adherence (e.g., incentives) & \\
\hline Objectives & 5 & - Specific objectives and hypotheses & \\
\hline \multirow[t]{3}{*}{ Outcomes } & \multirow[t]{3}{*}{6} & - Clearly defined primary and secondary outcome measures & \\
\hline & & $\begin{array}{l}\text { Methods used to collect data and any methods used to enhance the } \\
\text { quality of measurements }\end{array}$ & \\
\hline & & $\begin{array}{l}\text { - Information on validated instruments such as psychometric and biometric } \\
\text { properties }\end{array}$ & \\
\hline Sample Size & 7 & $\begin{array}{l}\text { - How sample size was determined and, when applicable, explanation of any } \\
\text { interim analyses and stopping rules }\end{array}$ & \\
\hline \multirow[t]{3}{*}{$\begin{array}{l}\text { Assignment } \\
\text { Method }\end{array}$} & \multirow[t]{3}{*}{8} & $\begin{array}{l}\text { - Unit of assignment (the unit being assigned to study condition, e.g., } \\
\text { individual, group, community) }\end{array}$ & \\
\hline & & $\begin{array}{l}\text { - Method used to assign units to study conditions, including details of any } \\
\text { restriction (e.g., blocking, stratification, minimization) }\end{array}$ & \\
\hline & & $\begin{array}{l}\text { - Inclusion of aspects employed to help minimize potential bias induced due } \\
\text { to non-randomization (e.g., matching) }\end{array}$ & \\
\hline
\end{tabular}


TREND Statement Checklist

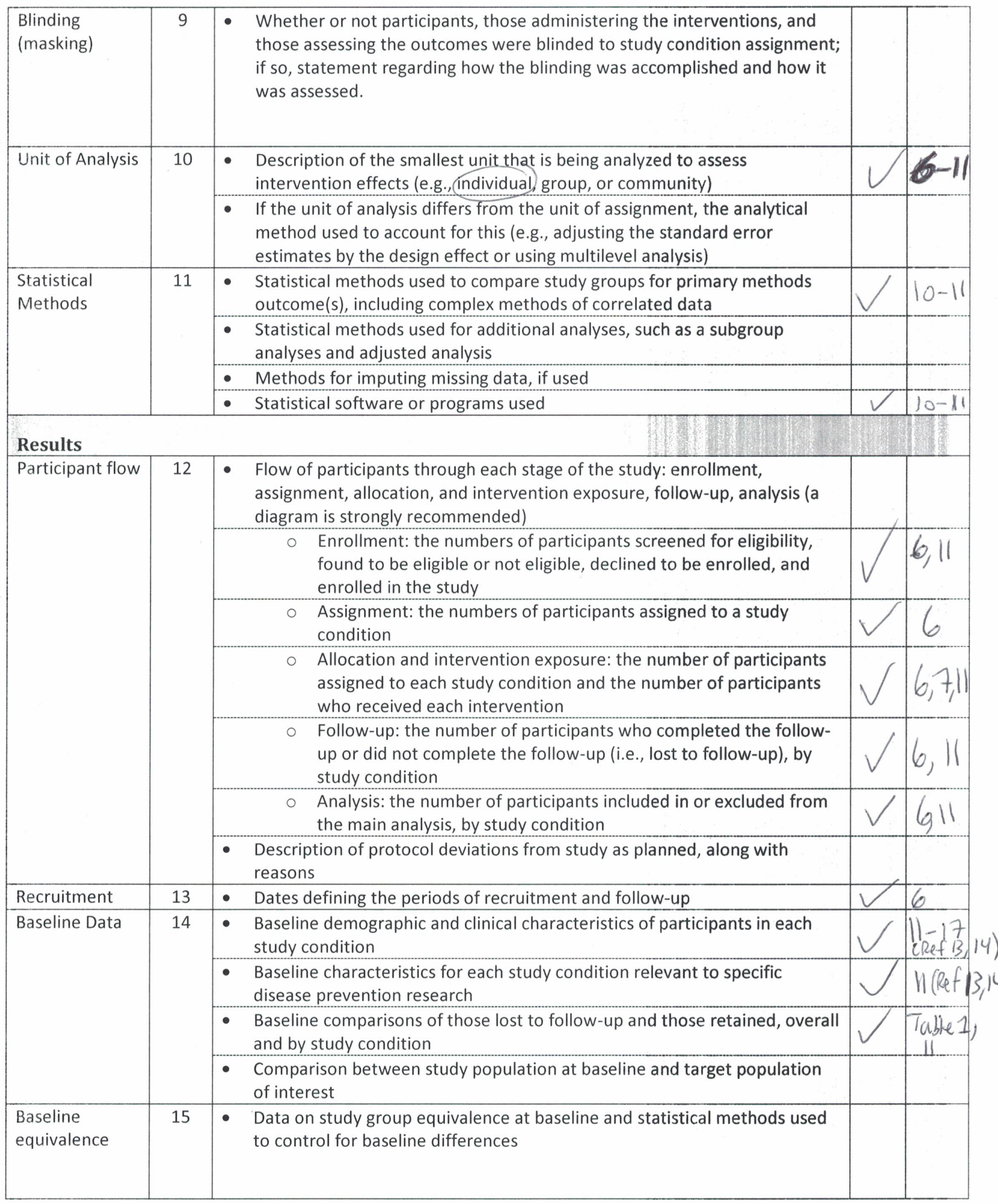




\section{TREND Statement Checklist}

\begin{tabular}{|c|c|c|c|}
\hline \multirow[t]{2}{*}{$\begin{array}{l}\text { Numbers } \\
\text { analyzed }\end{array}$} & \multirow[t]{2}{*}{16} & $\begin{array}{l}\text { - Number of participants (denominator) included in each analysis for each } \\
\text { study condition, particularly when the denominators change for different } \\
\text { outcomes; statement of the results in absolute numbers when feasible }\end{array}$ & \\
\hline & & $\begin{array}{l}\text { - Indication of whether the analysis strategy was "intention to treat" or, if } \\
\text { not, description of how non-compliers were treated in the analyses }\end{array}$ & \\
\hline \multirow[t]{3}{*}{$\begin{array}{l}\text { Outcomes and } \\
\text { estimation }\end{array}$} & \multirow[t]{3}{*}{17} & $\begin{array}{l}\text { - For each primary and secondary outcome, a summary of results for each } \\
\text { estimation study condition, and the estimated effect size and a confidence } \\
\text { interval to indicate the precision }\end{array}$ & \\
\hline & & - Inclusion of null and negative findings & \\
\hline & & $\begin{array}{l}\text { - Inclusion of results from testing pre-specified causal pathways through } \\
\text { which the intervention was intended to operate, if any }\end{array}$ & \\
\hline $\begin{array}{l}\text { Ancillary } \\
\text { analyses }\end{array}$ & 18 & $\begin{array}{l}\text { - Summary of other analyses performed, including subgroup or restricted } \\
\text { analyses, indicating which are pre-specified or exploratory }\end{array}$ & \\
\hline Adverse events & 19 & $\begin{array}{l}\text { - Summary of all important adverse events or unintended effects in each } \\
\text { study condition (including summary measures, effect size estimates, and } \\
\text { confidence intervals) }\end{array}$ & \\
\hline \multicolumn{4}{|l|}{ DISCUSSION } \\
\hline \multirow[t]{4}{*}{ Interpretation } & \multirow[t]{4}{*}{20} & $\begin{array}{l}\text { - Interpretation of the results, taking into account study hypotheses, } \\
\text { sources of potential bias, imprecision of measures, multiplicative analyses, } \\
\text { and other limitations or weaknesses of the study }\end{array}$ & \\
\hline & & $\begin{array}{l}\text { - Discussion of results taking into account the mechanism by which the } \\
\text { intervention was intended to work (causal pathways) or alternative } \\
\text { mechanisms or explanations }\end{array}$ & \\
\hline & & $\begin{array}{l}\text { - Discussion of the success of and barriers to implementing the intervention, } \\
\text { fidelity of implementation }\end{array}$ & 0 \\
\hline & & - Discussion of research, programmatic, or policy implications & \\
\hline Generalizability & 21 & $\begin{array}{l}\text { - Generalizability (external validity) of the trial findings, taking into account } \\
\text { the study population, the characteristics of the intervention, length of } \\
\text { follow-up, incentives, compliance rates, specific sites/settings involved in } \\
\text { the study, and other contextual issues }\end{array}$ & \\
\hline $\begin{array}{l}\text { Overall } \\
\text { Evidence }\end{array}$ & 22 & $\begin{array}{l}\text { - General interpretation of the results in the context of current evidence } \\
\text { and current theory }\end{array}$ & 7.20 \\
\hline
\end{tabular}

From: Des Jarlais, D. C., Lyles, C., Crepaz, N., \& the Trend Group (2004). Improving the reporting quality of nonrandomized evaluations of behavioral and public health interventions: The TREND statement. American Journal of Public Health, 94, 361-366. For more information, visit: http://www.cdc.gov/trendstatement/ 